\title{
Gold in Mosaic Art and Technique
}

\author{
Gianfranco Bustacchini
}

Academy of Fine Arts, Ravenna, Italy

\begin{abstract}
One of the most remarkable and fascinating uses of gold is in the art of mosaic. This most lovely and permanent form of decoration gives both an extraordinary splendour and yet a simplicity of dramatic quality in its representations. This article reviews both the development of the art of mosaic and the technical processes behind the achievement of the characteristic effects of richness and brilliance.
\end{abstract}

Mosaic work is as ancient as any other art form, although its technique, in becoming ever more complex and exacting, represents an artistic expression which is not spontaneous but indicative of a highly cultured environment, so that anyone who, when confronted by a brilliant Byzantine mosaic, naively believed it to be the outcome of a single culture would be totally mistaken.

In 2500 B.C. the Sumerians were already covering walls and columns with decorative motifs composed of tiny clay cones the bases of which, projecting from the wall, were glazed or rather dyed by an encaustic process. Very few colours were used: black, white, red and occasionally blue. The half-columns of Uruk, now known as Warka, in Mesopotamia, are very well known.

From the earliest dynasties the Egyptians used enamel colours for decorative purposes, as well as glazed polychrome bricks to decorate tombs such as that of Sethos I at Abydos. Alexandria in particular was an extremely important mosaics centre.

Mosaics have been found in the ruins of ancient Greek cities such as Corinth, Sparta and Olympia, dating from the fifth century B.c. These mosaics are rather poor, making no attempt at colour effects, small unwrought and unsmoothed stones being arranged to represent animals or simple hunting scenes.

Later, a more refined Hellenic culture made use of valuable marbles, onyx and serpentine, renowned for its hardness; even modest buildings and private houses boasted floors and walls decorated with mosaics.

When the Romans came to power, this and every other form of artistic expression were assimilated by the conquerors, carried and spread throughout the empire from North Africa to the Black Sea, from Asia to Spain, and as in the case of Greek statuary, Rome and other cities in which rich patricians lived began to acquire copies of Grecian mosaics executed by famous artists such as Soso of Pergamon and
Asclepiades of Arado, or similar to those in the Pompeii villa said to have belonged to Cicero.

The material most favoured by the Romans was derived from limestone, this being easier to handle than volcanic rock such as granite or porphyry. To intensify the colouring, these marbles were subjected to varying degrees of heat, or were tinted with solutions based on colour pigments. Vitreous materials were seldom used and gold appeared even more rarely, especially in floor mosaics.

Under the Romans, mosaic work, even if originating from different schools, acquired a rather standardised and uniform quality, moving away from the naturalistic Hellenic tradition. So widespread was its use that the Emperor Diocletian in the third century A.D. issued a decree establishing rates of pay for the various grades of mosaic artists; the highest rate went to the "Pictor Imaginarius" who created the original sketch or painting, then followed the "Pictor Parietarius" who transferred the design and colours to the walls or vaults, finally the "Musivarius" who applied the mosaics to the plaster.

With the triumph of Christianity over paganism, wall mosaics took pride of place as the only form of decoration in churches and sacred buildings in general.

When in A.D. 330 the Emperor Constantine transferred the Imperial Seat from Rome to Byzantium, the art of mosaics underwent an important development. Facilities granted to Roman and Greek artists, such as an imperial decree granting tax exemptions, were very favourable to this art form, which soon evolved into a great school. Contact with Byzantine painting raised it to a dominating position in Roman artistic circles and to the role of guiding light within the Christian orbit.

We value particularly the chromatic nuances and the glitter of gold used on a vast scale to form a truly astonishing backcloth on which figures and objects stand out with quite extraordinary effect, so that the texture of the work, fragmented by myriads of tiny 


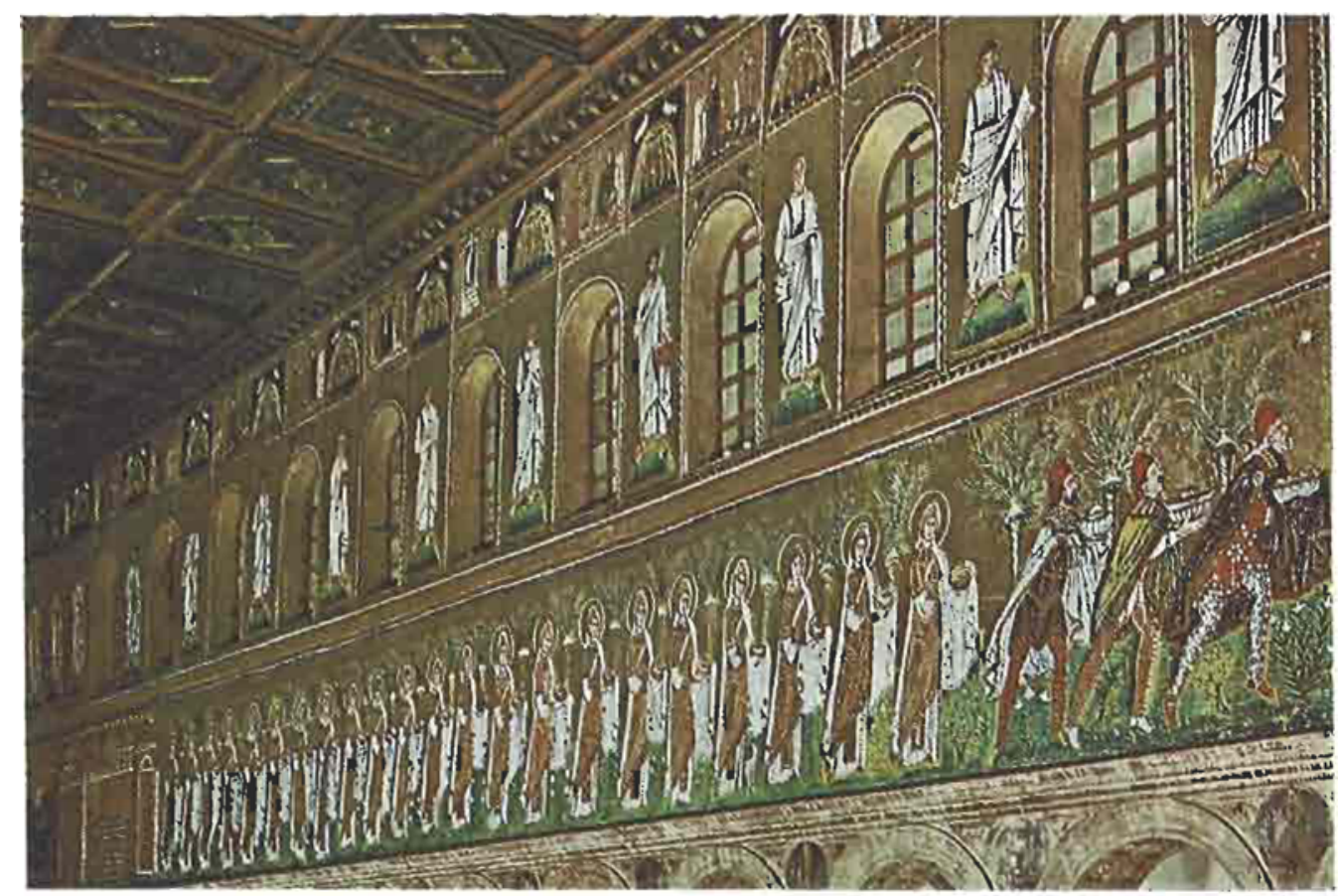

The mosaics of Ravenna are the most typical examples of the Byzantine style that are still preserved. In the church of Saint Apollinare Nuovo, built at the beginning of the sixth century by Theodoric, King of the Goths, both walls of the nave are covered with the most magnificent mosaics. The left wall shows a procession of twenty-two virgins, led by the three Magi, leaving the port of Classis, all on a gold hackground, with gospel scenes in the upper band and prophets between the windows

glazed cubes of varying sizes and facets which create infinite chromatic variations (and are aptly known as "Tessera" from the Latin "Tessellae" or "Tesserae" hence mosaic work= "Opus Tesselatum") regains its unity of composition when viewed from a distance.

The technique for gilding tesserae then consisted in the cold application of very fine gold leaf to a sheet of plain or lightly tinted glass about $8 \mathrm{~mm}$ thick, covering the gold with a layer of powdered glass, then firing; the resulting material was ideal for producing colour effects because the unevenness of the powdered glass and consequently of the overall thickness, created variations in tone and enabled gold to be used on very large areas.

We must indeed admit that, while in other types of painting the colours are often affected by fading,

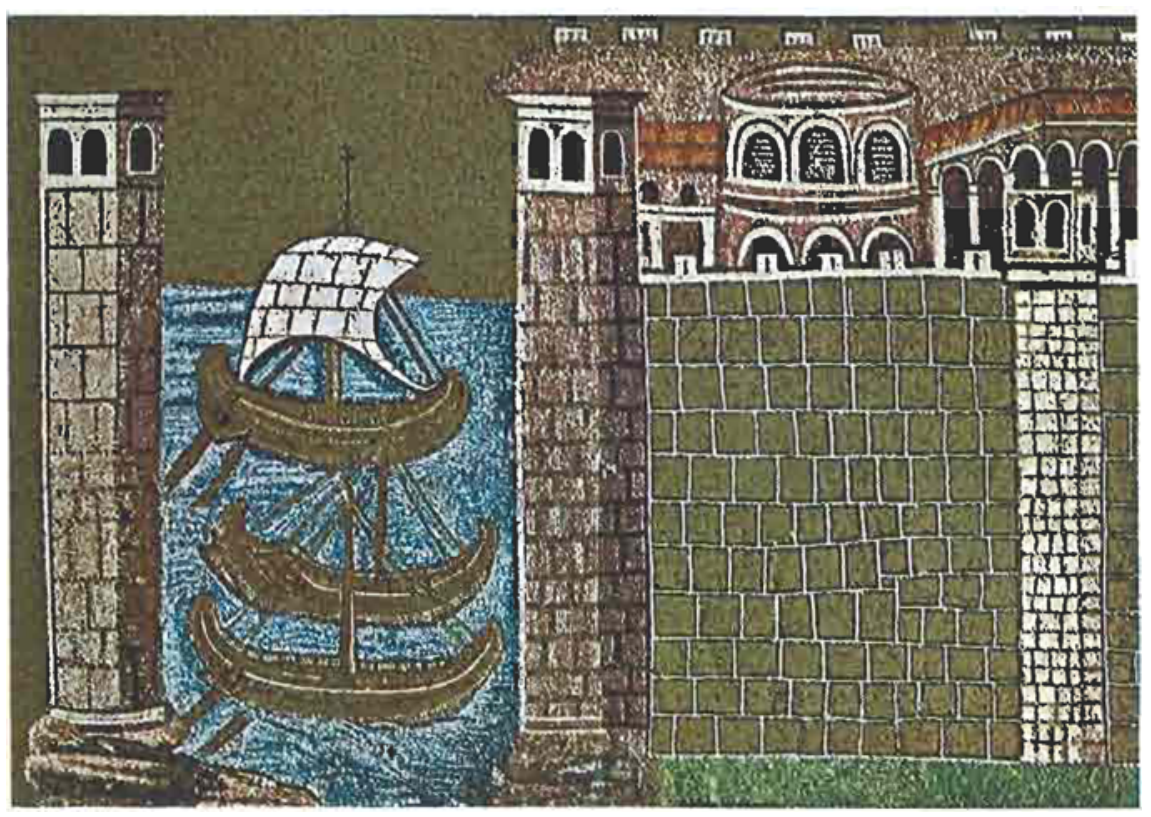

This detail from the chureh of Saint Apollinare Nuovo shows the port of Classis, founded by the Emperor Augustus in the first century B.C. as a base for the Roman fleet 


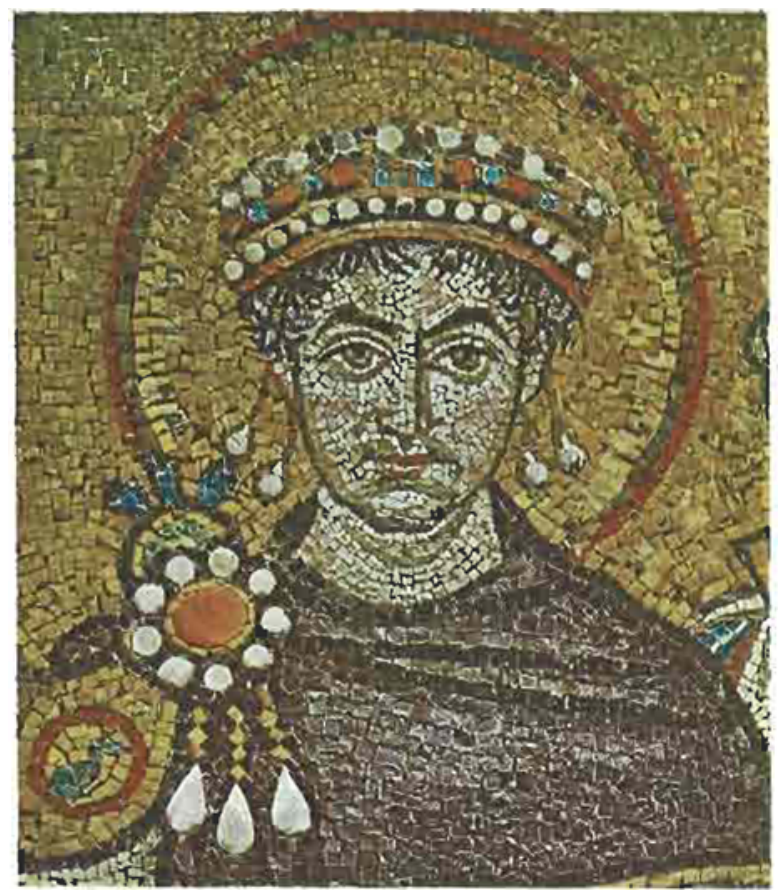

darkening, or mould, gilded and glazed mosaics in general have the great advantage of retaining their pristine hues. A typical example of this property can be seen at Ravenna, which is now eight kilometres from the sea but was formerly built on a lagoon like Venice, and was later surrounded by marshes for several centuries. In a damp region such as this, fabulous mosaics from the fifth and sixth centuries still retain their glorious brilliance. When the famous fifteenth-century painter, Ghirlandaio, referred to mosaics as "Paintings for Eternity" he was not just passing a casual remark.

Reverting to this feature which gold mosaic surfaces have of "generating" light, I should like to quote this
The Enperor Justinian, ruling over the East Roman Empire from Constantinople, conquered the Western Empire ruled from Ravenna in 540. This detail of his head from the ehurch of San Vitale in Ravenna forms part of a large mosaic, executed in about 548, depicting the Emperor and his court. The individual gold tesserae, placed at slightly different angles, give a scinillating effeet to the background

beautiful hexameter by an unknown poet, a contemporary of Theodoric, King of the Goths, written in mosaics in the Archbishop's Chapel at Ravenna (sixth century): "Aut lux hic nata est aut capta hic libera regnat" ("either light was herein born or else here imprisoned freely ruled"). The gilded interior of this mystic chapel does indeed ignore the properties of perspective and psychological effect, transporting the observer into a world of pure light in which all material considerations fade away.

The fame of Byzantine mosaics artists was such that Islamic rulers had recourse to Byzantine labour, as evidenced by the floral motifs with areas of gold on a deep blue background decorated with acanthus leaves, in the Cathedral of the Rock of Jerusalem and also in the Mosque at Damascus dating from about the same period (715).

With the fall of Constantinople during the Fourth Crusade in the thirteenth century Venice attracted Greek and Byzantine craftsmen in glass and it was at this time that the still flourishing art of glass blowing was born. The mosaics in the Basilica of St Mark, known as the Golden Basilica because of the extensive use of gold backgrounds-which unfortunately have been badly restored on several occasions-date from soon after this period.
Today the Mosaic Group of the Academy of Fine Arts in Ravenna is engaged not only on restoration work but on the making of copies of the classical mosaics. This reproduction is copied from a detail in the apse of the great ehurch of A pollinare in Classe, huilt in ahout 545 some six kilometres outside Ravenna

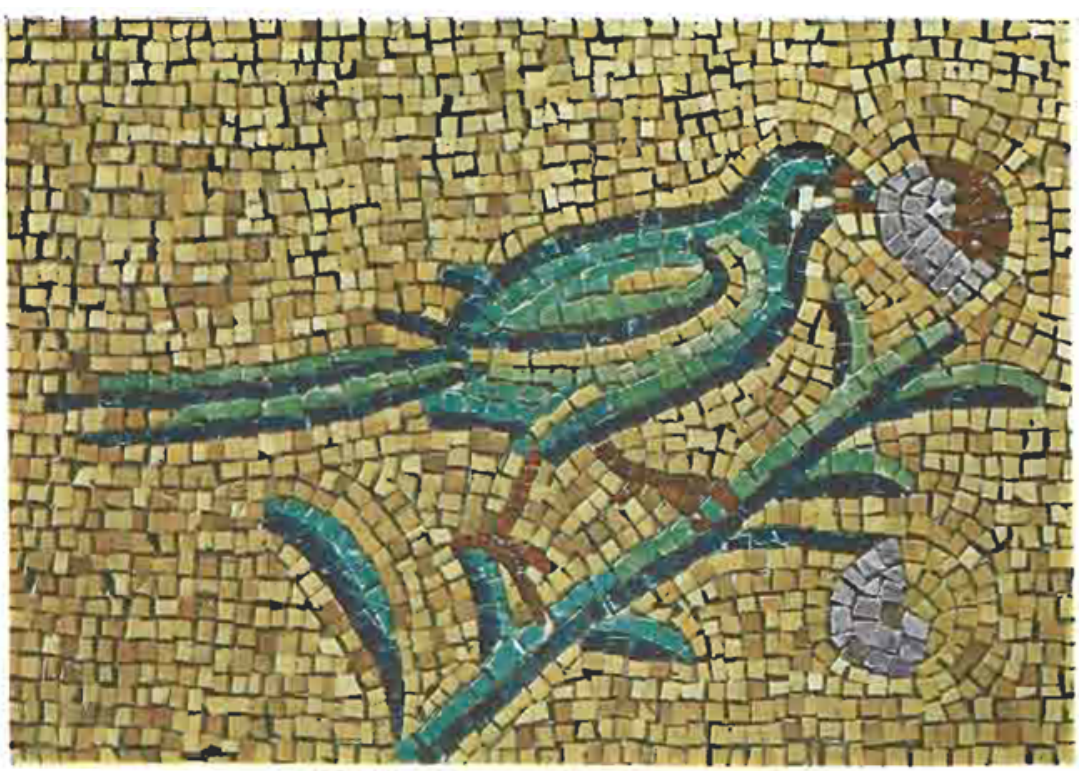


The Golilen Room in the Stockholm Gity Hall constitutes an excellent example of the revival of mosaic decoration in modern style. Designed by Einar Forseth in 1921-23, the gold backgrounds of the mosaies give an almost Byzantine glow to the scenes of Nordic mytlı and history. This wall carries a representation of Stoekholm in nuedieval times

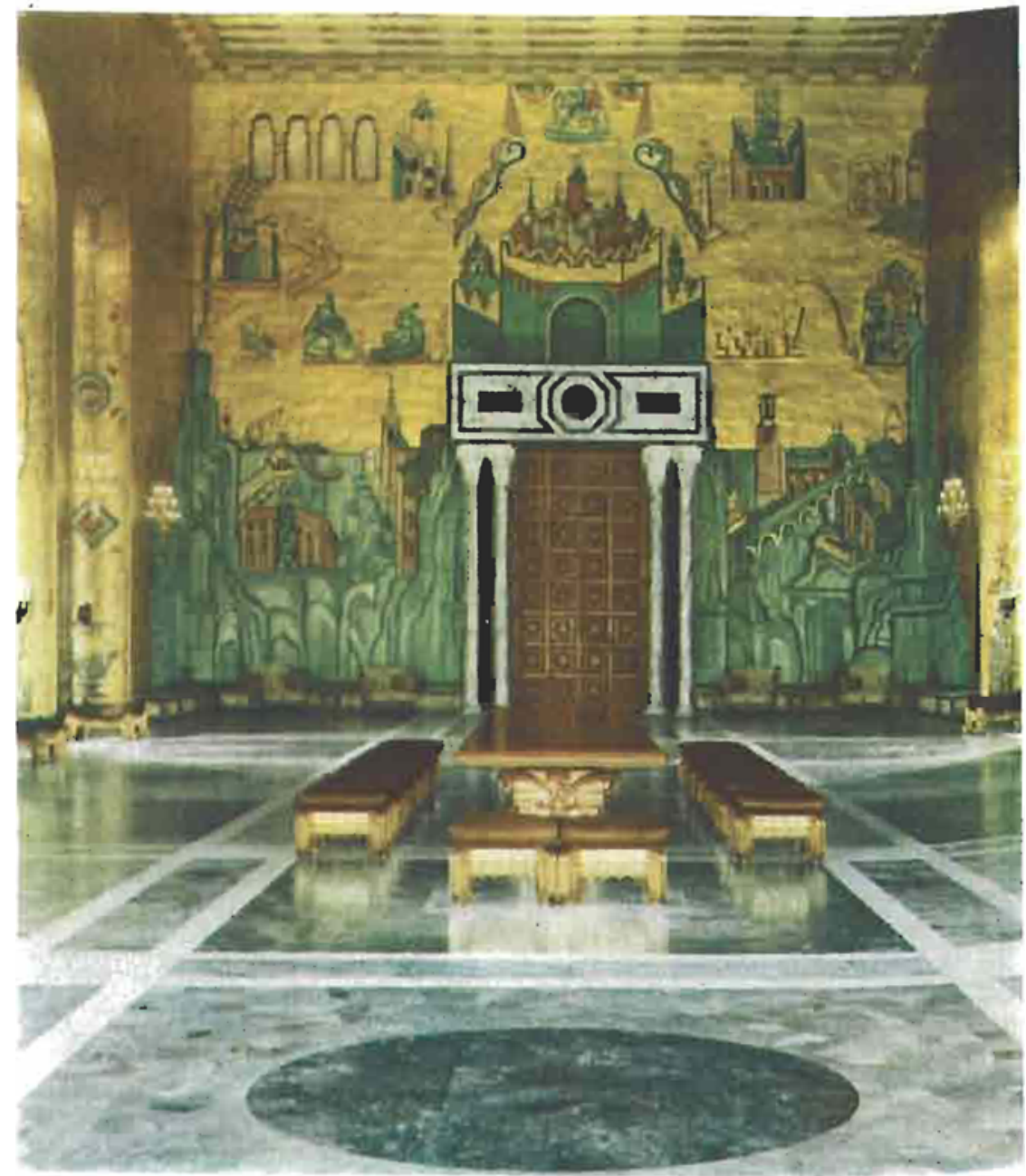

It was left to the master glassblowers of Venice to solve the only problem arising from the ancient technique of gilding tesserae-a problem which I personally encountered in the Ravenna mosaics, namely, that either the crystalline matter becomes detached from the vitreous base embedded in the plaster or else the crystalline substance breaks off complete with its layer of gold. The reason for this is that a tessera is not a compact body and tends to flake at its weakest point, where the layer of gold is joined to the glass base or to the vitreous paste. Consequently in the fifteenth century the master glassblowers evolved a heat process by which gold leaf was applied to a sheet of glass and a thin layer of molten glass was then blown over the gold; by carrying out these operations at high temperatures maximum adherence and solidity were ensured.

While these developments were taking place in Venice, this art was flourishing with renewed vigour in Sicily. This is borne out by the twelfth century Duomo at Monreale, a remarkable example of largescale composition, its mosaics covering an area of 600 square metres. The decorative motifs are singu- larly striking, the dominant theme again being one of gold surfaces. These gilded tesserae, used so sparingly by the Romans only when the artist wished to highlight or emphasise a detail, here cover vast sections in a dazzling display forming the centrepiece of the composition, and radiating a feeling of unreality evocative of the East.

The popularity of mosaics began to decline in the thirteenth century and during the fourteenth century the art fell into disuse, being superseded by painting on panels, canvases and frescoes. The few remaining factories only produced occasional batches of materials required in the restoration of ancient mosaics.

The dawn of the twentieth century heralded a revival of decorative mosaics. Thanks to modern casting techniques and the greater variety of precious minerals now available, artists today have at their disposal a very extensive range of colours; whereas ancient craftsmen used about 250 to 400 shades, the Mosaics Group of the Academy of Fine Arts in Ravenna has a range of about 8500 hues.

An improved process for gilding tesserae has also been adopted, although the materials used and their 
outward appearance remain unchanged. A 24-carat gold leaf, hand-beaten into a square measuring $10 \times 10$ $\mathrm{cm}$ and weighing $0.022 \mathrm{~g}$ is applied cold to an almost circular damp glass surface $1.0 \mathrm{~mm}$ thick, either natural or lightly tinted, over which is poured $200 \mathrm{~g}$ of molten glass which may be coloured (yellow, green, amber, etc.). After firing at $1200^{\circ} \mathrm{C}$ the materials are left in the kiln about 3 to 4 minutes until they become soft and are then allowed to cool to $600^{\circ} \mathrm{C}$, when they are returned to the kiln and annealed, then left to cool gradually to room temperature. Any burrs not containing gold are trimmed off and the material is cut into strips, to be sold in rods measuring $2 \times 10 \mathrm{~cm}$ approximately. The artist will then cut the rod into tesserae of the required size.

At this point I think it advisable to point out the considerable difference existing between the two most widely-used techniques in mosaic composition, the first being known as "Venetian" and the second as "Ravennate".

The Venetian technique consists in gluing (with any hydrosoluble agent) the upper part of the tessera (the one which will be visible in the pattern) on to a sheet of firm paper or cardboard on which the figure or pattern to be reproduced has previously been drawn or coloured, without any space being left between the various tesserae. When the composition has been completed, the mosaics are pressed into a sand and cement mixture. After the mixture has hardened, both glue and paper can be removed with boiling water, rubbing energetically with brushes of vegetable origin. The resulting surface will be completely smooth, flat and unbroken, ideal for floors, tables, etc.

The Ravennate technique enables the progressive creation of the design to be seen, as each individual tessera is attached directly to a blend of cement, sand and inert lime (so that it will "take" more slowly) on which the subject has been either painted or just sketched. Each tessera protrudes at a particular angle to the level of the plaster in accordance with specific light and vibration requirements or any three-dimensional effects which the artist may wish to create.

Gold tesserae in particular have this property of exploiting the dynamism of light refraction. Anyone who has seen the Ravenna mosaics at different times of day has remarked that the gilded background "relives" at each instant.

Regarding the binders used in mosaic work, these have kept pace with the evolution of building material technology. Whereas the Greeks used lime mixed with marble dust, baked brick and crushed pumice, the Romans added Pozzuolana and sand. It was only towards the end of the nineteenth century that Portland cement revolutionised every technique that had been previously tried out and simplified every operation. Today synthetic resins offer other alternatives; being lighter and more flexible, they allow more daring compositions to be devised.

It would appear that modern art, which is so often characterised by an almost frantic search for new forms of expression, in the course of its evolutionary process sometimes reverts to older forms, and a forgotten craft is revived and adapted to suit even the most advanced expressions of contemporary art. We believe, therefore, that mosaics will once again make a meaningful contribution to architecture, both civil and religious, and indeed this seems to be happening already.

$\mathrm{T}$

HEN among metals nothing is more sad in substance, or more better compact, than golde; and therefore though it bee put in fire, it wasteth not by smoaking or vapours, neither lesseth the waight, and so it is not wasted in fire; but if it be melted with strong heate, then if any filth be therein, it is cleaned thereof, and that maketh the golde more pure and shining. No metall stretcheth more with hammer worke, than golde, for it stretcheth so, that betweene the anfield and the hammer without breaking and renting into pieces, it stretcheth to leaf golde.

From the translation by

BARTHOLOMAEUS ANGLICUS

Dr Stephan Batman,

De Proprietibus Rerum

London, 1582

Nagdeburg, I 250 